\title{
Os enigmas de um formulário médico
}

\author{
Enigmas of a medical form
}

Los enigmas de un formulario médico

FORMULÁRIO MÉDICO: MANUSCRITO ATRIBUÍDO AOS JESUÍTAS E ENCONTRADO EM UMA ARCA DA IGREJA DE SÃO FRANCISCO DE CURITIBA. Gesteira HM, Leal JEF, Santiago MC, organizadores. Rio de Janeiro: Editora Fiocruz; 2019. 416 p. (Coleção História \& Saúde). ISBN 978-85-7541-633-4.

doi: 10.1590/0102-311X00014420

As primeiras décadas da ocupação europeia no continente americano aconteceram sob o imaginário acerca do "Novo Mundo" como um território onde as enfermidades eram relativamente raras e de pouco impacto na existência humana. No entanto, já nos meados do século XVI essa imagem paradisíaca estava sendo substituída pelas ponderações que apresentavam a colônia lusitana situada na América como um inferno, onde a sina dos colonos era deparar-se com uma grande variedade de doenças desconhecidas e mortais.

Nesse contexto, uma das estratégias implantadas para garantir a vida e a continuidade do processo de ocupação da América portuguesa constituiu na articulação de um inovador conhecimento sobre as enfermidades e as terapêuticas, o qual foi preservado nos formulários médicos. Um valioso exemplo desse tipo de documento é um manuscrito que atualmente está depositado na Biblioteca de Manguinhos (Fundação Oswaldo Cruz) e que, segundo informações escritas posteriormente na sua página inicial, é datado de 1703 e foi encontrado em uma arca pertencente à Igreja de São Francisco de Curitiba. Apesar disso, há muito de nebuloso sobre esse documento: teria sido produzido mesmo na data indicada? Quem seria seu autor? Seria ele um jesuíta? Teria sido escrito nas capitanias do sul da colônia?

A tentativa de elucidação dessas questões levou à formação de um grupo de especialistas em história da medicina, paleografia e arquivologia. Entendido como um artefato, o manuscrito foi submetido a vários testes laboratoriais e análises de conteúdo, sem que fosse possível chegar-se a conclusões incontestáveis sobre sua produção e possível utilização no século XVIII. Tais limitações, no entanto, não diminuem a importância desse formulário médico, apenas ampliam o desejo de conhecê-lo melhor.

A leitura do manuscrito expõe o intento do seu compilador de sistematizar um conhecimento importante e útil para a sobrevivência da população colonial. Nas centenas de receitas que objetivavam socorrer as vítimas de praticamente todas as doenças então reconhecidas no Brasil, fica implícita a intenção inicial de o formulário tentar apoiar-se, sobretudo, nos ensinamentos hipocráticos-galênicos, acrescidos de elementos da medicina elaborada pela modernidade clássica. No entanto, as novidades patológicas apresentadas pela colônia e o alto custo das drogas importadas fizeram o autor recuar e incorporar elementos das terapêuticas indígenas e africanas, substituindo itens da farmácia europeia ou a ela acrescentado substâncias próprias da América e 
da África, como raízes de diferentes plantas e árvores, empregando em muitas prescrições terapêuticas ensinamentos da medicina escatológica, como a recorrência ao esterco humano e também de cavalo, galinha, coelho e lagartixa.

Paralelamente a isso, a compilação de receitas por um autor que permanece na penumbra não pode ser avaliada como uma produção original. Ele próprio remeteu a outros personagens, inclusive um coronel do qual adotou várias recomendações terapêuticas e um certo padre Ciebra, de quem copiou parte do "tratado de vários medicamentos". Além da consulta a outros formulários, ele também incorporou elementos da cultura popular e consultou obras que versavam sobre as virtudes terapêuticas das substâncias animais, vegetais e minerais corriqueiras na América, sendo possível identificar um grande número de informações semelhantes às anotadas pelo holandês Guilherme Piso 1, médico pessoal de Maurício de Nassau quando de sua permanência em Pernambuco.

Ao lado das tensões próprias de uma cultura médico-terapêutica híbrida, notam-se também convergências. Parte do receituário remete aos ensinamentos de Paracelse 2 sobre a "doutrina de assinaturas", que informava que a natureza guardava oculta substâncias específicas para doenças específicas, cabendo ao pesquisador "ler" o mundo natural e desvendar os sinais, geralmente o formato e as cores das plantas e dos minérios, que encaminhavam ao reconhecimento de drogas curativas. Da mesma forma, Lévi-Strauss 3 expôs que o pensamento das sociedades de estrutura simples identificava os elementos curativos na natureza com base em sua forma e coloração, fenômeno comum entre a população autóctone da América.

Outra questão fundamental para a avaliação do Formulário de 1703 consiste nas possibilidades de sua circulação. A Companhia de Jesus era a instituição religiosa que mais se dedicava aos trabalhos nas boticas, havendo a chance de o autor do Formulário ter sido ele próprio um jesuíta, guardando certos segredos das receitas das drogas, como era o caso da triaga, complexa composição administrada para praticamente todas as doenças, acidentes peçonhentos e envenenamentos propositais. Se assim for, havia uma intensa troca de conhecimentos entre os Inacianos que atuavam na Europa, América, África e Ásia, e é possível que os receituários elaborados em várias partes do planeta tenham sofrido influências mútuas, sendo adaptados às necessidades e à disponibilidade de drogas de cada região.

Existe, porém, um outro roteiro de circulação do conhecimento, restrito à esfera de uma mesma colônia. A importância do documento analisado é inegável, mas cabe uma questão: se ele era empregado pelos boticários para a elaboração de remédios e prescrição aos enfermos, tal conhecimento e mesmo as drogas chegavam à população em geral? Os comentaristas da obra aqui vistoriada acreditam que sim, mas também é necessário levar-se em consideração que as boticas vendiam os remédios, sendo que tal atividade era uma importante fonte de recursos para algumas ordens religiosas. Quando as composições medicamentosas empregavam substâncias importadas, como o vinho branco lusitano e a pedra benzoar asiática, o preço do remédio elevava-se a um patamar que tornava impossível sua aquisição por boa parte da população, especialmente os paupérrimos habitantes das capitanias localizadas no sul da colônia.

Existe uma vasta documentação que se refere à incapacidade econômica da população em comprar os produtos elaborados pelos boticários, havendo períodos em que a administração colonial punia como criminosos aqueles que, sem autorização, produziam drogas ou faziam uso delas. Em 1746, Dom Luiz Mascarenhas 4, um capitão-general de São Paulo, alegou que os remédios das boticas eram "raros e caros" e, por isto, pediu a suspensão das queixas dos médicos e dos boticários contra os "remédios do povo", isto é, as drogas preparadas exclusivamente segundo os preceitos das culturas indígena e africana. Duas décadas depois, outro capitão-general de São Paulo, Dom Luis Antonio de Souza Botelho Mourão 5, mais conhecido como Morgado de Matheus, assinou uma petição semelhante, acrescentando que, acometido de uma enfermidade e após fazer uso sem qualquer efeito positivo dos remédios prescritos por médicos e boticários, havia se curado "ao modo do povo".

Era comum também que as expedições mais prósperas que rumavam para o sertão levassem 
na bagagem quantidades limitadas de drogas adquiridas em boticas. No entanto, como as expedições demoravam anos para retornarem ao local de onde partiram, às vezes mais de uma década, os remédios acabavam rapidamente e, a partir de então, passava-se a fazer uso da medicina dos indígenas e dos africanos, que era praticada por alguns escravos que integravam as comitivas. Os relatórios compilados por Taunay 6,7 deixam claro as dificuldades de sobrevivência no sertão e o amplo uso das estratégias terapêuticas dos nativos e dos africanos. Caso nem mesmo isso fosse possível, o caminho escolhido era o apelo à piedade e à proteção dos santos católicos que, aliás, foi um dos elementos relacionados no Formulário de 1703 para dor de dente ou quando uma pessoa estava em risco de morrer afogada ou durante um incêndio.

Para além dessas ponderações, acredita-se que o Formulário de 1703 revela-se uma importante fonte não só para o conhecimento da medicina e das terapêuticas implantadas no ambiente colonial, como também uma preciosa janela para o entendimento das estratégias de sobrevivência e das mentalidades que caracterizaram os primeiros séculos da colonização do Brasil.

\section{Cláudio Bertolli Filho ${ }^{1}$}

1 Faculdade de Arquitetura Artes e Comunicação de Bauru, Universidade Estadual Paulista Júlio de Mesquita Filho, Bauru, Brasil.

cbertolli@uol.com.br.

\section{Informação adicional}

ORCID: Cláudio Bertolli Filho (0000-0003-35849736).

1. Piso G. História natural e médica da Índia Ocidental. Rio de Janeiro: INL; 1957.

2. Paracelse. Oeuvres médicales. Paris: PUF; 1968.

3. Lévi-Strauss C. O pensamento selvagem. São Paulo: Companhia Editora Nacional; 1976.

4. Mascarenhas L. Reg.to de hu bando pelo qual se concede faculdades aos Cirurgioens, e Curiozos das minas de Goyás p. a poderem curar toda a casta de Enfermidades. In: Documentos interessantes para a história e costumes de São Paulo. v. 22. São Paulo: Arquivo Público do Estado; 1896. p. 190-2.

5. Mourão LASB. Ofício. In: Documentos interessantes para a história e costumes de São Paulo. v. 73. São Paulo: Arquivo Público do Estado; 1952. p. 45.

6. Taunay AE. Relatos sertanistas. São Paulo: Edusp/Belo Horizonte: Itatiaia; 1981.

7. Taunay AE. Relatos monçoeiros. São Paulo: Edusp/Belo Horizonte: Itatiaia; 1981.

Recebido em 27/Jan/2020

Aprovado em 04/Fev/2020 